\title{
Studies on Mutagenic Efficiency and Effectiveness of Sodium Azide on Indian mustard in $\mathbf{M}_{2}$ Generation
}

\author{
K.S. Gowtham ${ }^{1 *}$, Beena Nair ${ }^{2}$, D. Manoj Kumar ${ }^{1}$ and P.D. Pawar ${ }^{1}$ \\ ${ }^{1}$ Agricultural Botany section, CoA Nagpur, India \\ ${ }^{2}$ AICRP on Mustard, CoA Nagpur, India \\ *Corresponding author
}

A B S T R A C T

\section{Keywords}

Mutagenic efficiency,

Mutagenic effectiveness,

Sodium azide, Brassica

juncea

Article Info

Accepted:

18 October 2018

Available Online:

10 November 2018
Mutagenic efficiency and effectiveness is an important factor for the selection of a mutagen for a mutation breeding program. The mutagenic efficiency gives an idea of the proportion of mutation on relation to the other associated undesirable biological effects such as lethality, sterility and meiotic aberrations while mutagenic effectiveness is a measure of the frequency of the mutation induced by unit dose of mutagens. The usefulness of any particular mutagen in crop breeding depends not only on its mutagenic effectiveness but also on the mutagenic efficiency of the mutagen. Studies on mutagenic efficiency and effectiveness of chemical mutagen sodium azide $\left(\mathrm{NaN}_{3}\right)$ on variety Pusa mustard 21 of Indian mustard have been reported. The treatments included three concentrations of sodium azide $(0.03 \%, 0.06 \%$ and $0.09 \%)$

\section{Introduction}

Rapeseed-Mustard are important oilseed crop of the world being grown in around 50 countries across the six continents. The crop is grown both in sub-tropical and tropical countries. Among different oilseed crops grown in India, the Rapeseed-Mustard (Brassica spp.) contributes $29.5 \%$ in the total production of oilseeds. In India, it is the second most important edible oilseed after groundnut sharing $27.8 \%$ in the India's oilseed economy (Anonymous, 2015). Indian mustard, Brassica juncea (L.) Czern and Coss $(2 \mathrm{n}=2 \mathrm{x}$ $=36$, genome $\mathrm{AABB}$ ) is the oldest of the cultivated amphidiploids. It is called as "rai", "raya" or "laha" is one of the important oilseed crops belonging to family cruciferae (Syn. Brassicaceae) and genus Brassica. The available evidences indicate that B.juncea was under cultivation in Indus valley in around 3000 BC. The species probably evolved in the Middle East, where its putative diploid progenitors Brassica rapa and Brassica nigra are sympatric (Prakash and Hinata, 1980). Mustard is largely self-pollinated crop but certain amount (5 - 18\%) of cross pollination may take place (Labana and Banga, 1984).

Complementing the conventional method, mutation breeding can play a unique role in crop improvement which provides a novel approach to plant breeders for raising the productivity and obtaining acquired result, 
when it is desired to rectify small defects in any crop variety. Mutation breeding techniques has been used to produce many cultivars with improved economic value (Van et al., 1990 and Bertagne, 1996). Induced mutations have great potentials and serve as a complimentary approach in genetic improvement of crops (Mahandjiev et al., 2001). Sodium azide is a chemical mutagen that creates point mutations, A. T--G. C, base pair transition and transversion in the genome of plants by producing metabolite and thus produced protein in mutant plant has different function from the normal plant (Khanand Fahad, 2009).

\section{Materials and Methods}

The present study is undertaken to estimate efficiency and effectiveness using different concentrations of sodium azide $\left(\mathrm{NaN}_{3}\right)$ in $\mathrm{M} 2$ generation of Indian mustard Brassica juncea var. Pusa mustard 21.P M 21 is a variety, low in erucic acid and well adapted to Vidarbha region of Maharashtra. Dry, healthy and genetically pure seeds of Brassica juncea cv. Pusa mustard 21 were divided into 4 lots of 300 seeds each for giving the sodium azide treatment, and one lot (300 seeds) among them was control. The three seed lots were treated with $0.03 \%, 0.06 \%, 0.09 \%$ aqueous solution of sodium azide for $18 \mathrm{hrs}$. After washing with sterilized water, the treated seeds were sown after one hour along with control. The sowing of $\mathrm{M}_{1}$ generation was done in November 2015 at research farm, college of agriculture, Nagpur. The treated seeds were used to raise $\mathrm{M}_{1}$ generation along with control. No observations were recorded in $\mathrm{M}_{1}$ generation except for germination and mortality percentage. $\mathrm{M}_{1}$ plants were harvest plant wise. Mutagenic frequency was calculated as percent of $\mathrm{M}_{2}$ plants as given by Gaul (1958). Mutagenic efficiency and effectiveness were calculated based on the formulae given by Konzak et al., (1965).

\section{Results and Discussion}

Mutation frequency of each visible mutant in $\mathrm{M}_{2}$ generation was calculated as suggested by Gaul (1958) and is represented in table 1. The table revealed that the treatment $\mathrm{T}_{3}$ induced the highest mutation frequency $(2.01 \%)$ followed by $\mathrm{T}_{1}(1.30 \%)$ and the lowest in $\mathrm{T}_{2}$ $(1.26 \%)$. The frequency of mutation was comparable in all the treatments.

Sathawane (2012) undertook mutagenic studies to produce yellow seed in Indian mustard. Yellow seed coat colour mutants were selected in $\mathrm{M}_{1}$ and $\mathrm{M}_{2}$ generations. Upon analysis of $\mathrm{M}_{1}$ and $\mathrm{M}_{2}$ mutation frequencies of data for yellow seed coat colour mutant, it was observed that sodium azide induced comparatively higher frequency than ethyl methane sulfonate. Sangsir et al., (2005) observed increase in frequencies over 430 characters with increase in doses of gamma rays and EMS in combination in mustard, and similar result found by Jain (2010) in Brassica juncea.

The concept of mutagenic efficiency and effectiveness was given by Ehrenberg (1960). From the table 1, it was noticed that the highest mutagenic efficiency was exhibited by $\mathrm{T}_{1}(0.472 \%)$ followed by $\mathrm{T}_{3}(0.423 \%)$, while the lowest efficiency was found in $\mathrm{T}_{2}$ $(0.387 \%)$. It was observed that in the variety $\mathrm{P}$ M 21, the lower concentration $0.03 \%$ SA has recorded highest mutagenic efficiency as compared other treatments. It does not follow a specific trend.

Mutagenic effectiveness is a measure of the frequency of the mutation induced by unit dose of mutagens (Konzak, 1965). Table 1 depicted that, among different treatments the highest mutagenic effectiveness was observed in $\mathrm{T}_{1}(0.024 \%)$ followed by $\mathrm{T}_{3}(0.013 \%)$, while the least effectiveness was recorded in $\mathrm{T}_{2}(0.012 \%)$. 
Table.1 Mutagenic efficiency and effectiveness of different concentrations of sodium azide in Brassica juncea (L.)

\begin{tabular}{|c|c|c|c|c|c|}
\hline $\begin{array}{l}\text { Sr. } \\
\text { No. }\end{array}$ & Treatments & $\begin{array}{c}\% \\
\text { Lethality } \\
\text { (L) }\end{array}$ & $\begin{array}{c}\% \text { Mutation } \\
100 \mathrm{M}_{2} \\
\text { Plants (MP) }\end{array}$ & $\begin{array}{c}\text { Mutagenic } \\
\text { efficiency } \\
\text { (MP/L) }\end{array}$ & $\begin{array}{l}\text { Mutagenic } \\
\text { effectiveness } \\
\text { (MP/tc) }\end{array}$ \\
\hline 1 & $\mathrm{~T}_{1}(0.03 \%)$ & 2.75 & 1.30 & 0.472 & 0.024 \\
\hline 2 & $\mathrm{~T}_{2}(0.06 \%)$ & 3.25 & 1.26 & 0.387 & 0.012 \\
\hline 3 & $\mathrm{~T}_{3}(0.09 \%)$ & 4.75 & 2.01 & 0.423 & 0.013 \\
\hline 4 & $\mathrm{~T}_{4}$ (Control) & 1.5 & - & - & - \\
\hline
\end{tabular}

The lower concentration i.e. $0.03 \%$ of SA showed highest mutagenic effectiveness in PM 21 as compared to other higher doses of SA. The mutagenic effectiveness does not follow a specific trend.

Sangle and Kothekar (2013) assessed the relative effectiveness and efficiency of the three mutagens in pigeon pea, from the data on biological damage in $\mathrm{M}_{1}$ generation and frequency of chlorophyll mutants in $\mathrm{M}_{2}$ generation. The effectiveness values decreases with the increasing concentration of gamma ray and SA treatments. In SA treatments the effectiveness values ranged from 0.372 to 0.754 and 0.470 to 1.066 in both the varieties respectively.

The mutation frequency did not follow a specific trend in any of the treatments. Mutagenic efficiency and effectiveness of a mutagen does not follow a specific trend. The mutagenic effectiveness was more in lower concentration of SA i.e. $0.03 \%$. The mutagenic effectiveness did not follow a specific trend.

\section{References}

Anonymous, 2015a. Proceeding of 22nd AGM of AICRP on rapeseed and mustard, pp 34.

Bertagne, S.B., G. Fouilloux, Y. Chupeau, 1996. Induced albino mutations as a tool for genetic analysis and cell biology in flax (Linum usitatssimum). Journal of J. Exp. Bot. 47: 189-194.

Gaul, 1958. Present aspects of induced mutation in Plant Breeding. Euphytica, 7: 275-279.

Jain, S.M., 2010. Mutagenesis in crop improvement under the climate change. Rom Biotechnol Lett. 15(2): 53-56.

Konzak, C.F., R.A. Nilan, J. Wanger and R.J. Feater, 1965. The use of induced mutation in Plant Breeding Supp. Rad. Bot., 5:49-80.

Labana, K. S. and S. K. Banga. 1984. Floral Biology in Indian mustard (Brassica juncea L.). Genet. Agri. 38: 131-138.

Mahandjiev, A., G. Kosturkova, M. Mihov, 2001. Enrichment of Pisum sativum gene resources through combined use of physical and chemical mutagens. Isr. J. Plant Sci. 49 (4): 279-284.

Prakash, S. and Hinata, K. 1980. Taxonomy, cytogenetics and origin of crop Brassica, pp 63-68.

Sangle, S.M. and Kothekar, V.S., 2013. Mutagenic effectiveness and efficiency in pigeon pea. International journal of advanced scientific and technical research. 4(3): 40-45.

Sangsir, C.W., Sorajjapinun and P. Srinivas, 2005. Gamma radiation induced mutations in mungbean. Sci. Asia. 31: 251-255.

Sathawane, K.N. 2012. Sodium azide (SA) induced higher mutations frequency of yellow seed coat colour in Brassica 
juncea (L.) Coss and Czern. Cv. Varuna. Bionano Frontier. 5(2-II): 128130.

Van, R.W. Bulk, H.J.M. Loffer, W.H. Lindhout, M. Koornneef, 1990.
Somaclonal variation in tomato: effect of explants source and a comparison with chemical mutagenesis. Theor. Appl. Genet. 80: 817-825.

\section{How to cite this article:}

Gowtham, K.S., Beena Nair, D. Manoj Kumar and Pawar, P.D. 2018. Studies on Mutagenic Efficiency and Effectiveness of Sodium Azide on Indian mustard in $\mathrm{M}_{2}$ Generation. Int.J.Curr.Microbiol.App.Sci. 7(11): 2253-2256. doi: https://doi.org/10.20546/ijcmas.2018.711.252 